Herodotus and the Origins of the Political Community 
This page intentionally left blank 


\section{Herodotus and the}

Origins of the

\section{Political Community}

Arion's Leap

Norma Thompson

Yale University Press New Haven and London 


\section{Copyright 1996 by Yale University.}

All rights reserved.

This book may not be reproduced, in whole or in part, including illustrations, in any form (beyond that copying permitted by Sections 107 and 108 of the U.S. Copyright Law and except by reviewers for the public press), without written permission from the publishers.

Designed by James J. Johnson and set in Monotype Baskerville types by Tseng Information Systems, Inc., Durham, North Carolina.

Printed in the United States of America by BookCrafters, Inc., Chelsea, Michigan.

\section{Library of Congress Cataloging-in-Publication Data}

Thompson, Norma, 1959-

Herodotus and the origins of the political community : Arion's leap / Norma Thompson.

p. $\mathbf{c m}$.

Includes bibliographical references and index. I8BN 0-300-06260-5 (alk. paper)

I. Herodotus-Political and social views. I. Title. JC71.H47T48 1996

$$
93^{8} .007202-\mathrm{dc20} \quad 95^{-260}
$$

A catalogue record for this book is available from the British Library.

The paper in this book meets the guidelines for permanence and durability of the Committee on Production Guidelines for Book

Longevity of the Council on Library Resources.

$$
\text { 10 } \begin{array}{lllllllll}
9 & 8 & 7 & 6 & 5 & 4 & 3 & 2 & 1
\end{array}
$$


To David Grene,

who saw that Herodotus

is Irish. 
"No anchor, no cable, no fences avail to keep a fact a fact."

-emerson, History 